\title{
耳鼻咽喉科領域の立体レ線撮影
}

\author{
宮本 和雄* ・北村 溥之・東辻 英郎 \\ 岸本 誠司**・斎藤 春雄***
}

\section{Stereoradiography in the Field of Otorhinolaryngology}

\author{
Kazuo Miyamoto*, Hiroyuki Kitamura, Hideo Higashitsuji \\ Seiji Kishimoto**, Haruo Saito*** \\ *(Oita Pref. Hosp.), **(Tenri Hosp., Nara), ***(Kyoto Univ.)
}

Recently we applied stereoradiography in the field of otorhinolaryngology and have reassessed its merits which are not evident in simple radiography or tomography, though the stereoradiography itself is not a novel method. Compared with tomography, stereoradiography is clearer by complement of two films and exposure time is short. Particular photographing devices are unnecessary as the site involved in the field of otorhinology does not move. Sites which overlap one another if taken by simple radiography become visible by stereoradiography. In the field of otorhinology in particular, it is quite easy to determine the exact position of the lesion as there are numerous osseous tissues.

An important factor on taking a picture is the moving-distance of the tube lamp. Such should not exceed $10 \%$ of the photographing distance.

Observation can be easily made by a handy typed prism stereoscope when naked eye observation is impossible. We therefore consider that stereoradiography has definite merits in the otorhinological field not only for advanced studies but also for clinical application, as the procedure is simple and easily facilitated.

は じめに

立体レ線撮影はことさら新しいものではないが, 我々はこの 2 年間, 耳鼻咽喉科領域のレ線診断 法の一貫としてての撮影法をとり入れ，その有用性を再認識した。乙の報告では, 撮影法, 観察法 を述へ，立体写真の実例を示し，その利点について考按を加えたい.

\section{撮影方法と観察方法}

1 ）立体レ線撮影法

撮影法には, (1)管球移動法, (2)被写体移動又
は回転法があるが，前者が一般的であり，撮影 屯容易である. 消化器や胸部の撮影では, 対象

\footnotetext{
*大分県立病院耳鼻咽喉科

**天理病院耳鼻咽喉科

***京都大学医学部耳鼻咽喉科学教室
} 


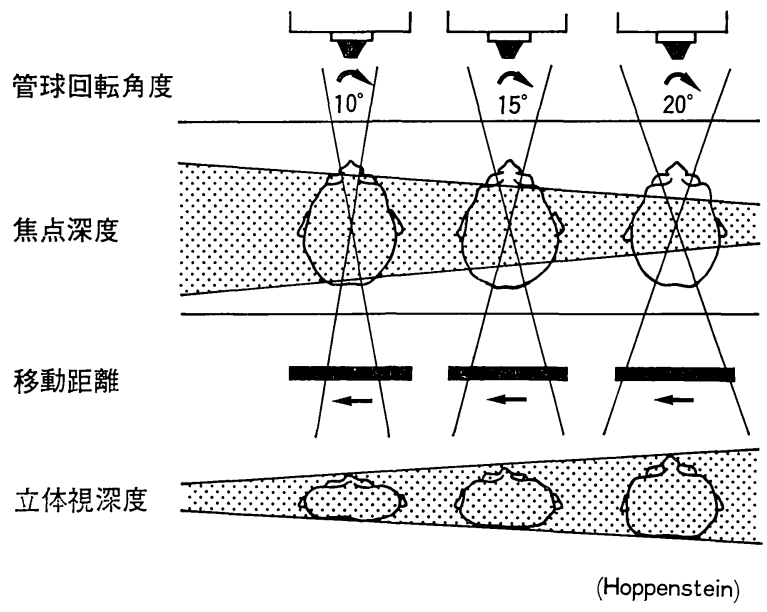

図 I

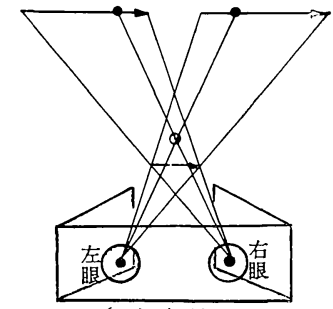

(a) 輻䡍視

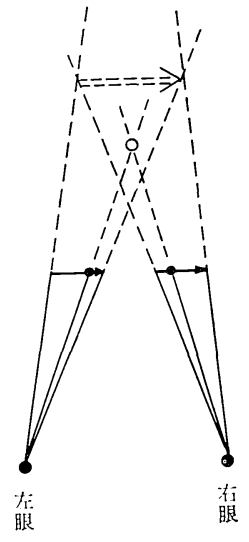

(b) 開散視

$\mathrm{a}$ はフィルムより近くを見つめそれぞれの眼で反対側のフ イルムを見る。

bは遠くに視線をやつて，それぞれ同側のフィルムを見る。 裸眼立体視の方法

(佐藤, 吉村, 江藤)

図 2

が軟部組織であったり，臓器の運動があったり するので，特殊な装置が考案されている ${ }^{11}$. し かし耳鼻科領域の疾患では, 動きのない骨部病 変を診るととが多いので, 特別な装置は必要と せず，普通の管球を用いた撮影で十分明瞭な立 体像が得られる，ところで，撮影距離に対する 管球の回転角度又は移動距離の比率は古来問題 となる所である。撮影距離に比し，管球回転角

度又は移動距離が過大であると，立体視効果は 大きいが，焦点深度は浅くなり，奥行の深い歪 んだ立体像となる。一方，管球回転角度又は移 動距離が過小であると，焦点深度は大きくなる が，立体視効果は悪く，奥行の浅い扁平な像が 得られる。乙れまでの報告によると，最む効果 的な立体を得る為の管球移動距離は撮影距離の 10\%を越えてはならないとされている2)31.（図 1 参照)

藤原 ${ }^{3}$ はこの関係を調べ，管球移動距離を $\ell$, 被写体の厚さを $\Delta$, 撮影距離を $\mathrm{d}$ とするれば $\ell$ は，

$$
0.7 \frac{\mathrm{d}}{\Delta}<\ell<1.3 \frac{\mathrm{d}}{\Delta}
$$

に示す範围がよいという結果を得ている。移動 距離を決めれば，通常の焦点位より移動距離の 半分づつの位置で撮影すればよい，その方向は 被写体の左右方向，上下方向いずれでも可能で ある。

2 ）立体レ線像の観察法

肉眼で立体感が得られるのは, 左右の網膜に 映った像の偏差が視覚中枢で調整されるからで ある. 従って， 2 枚のフィルムを左右別々の眼 で見れば立体感は得られることになる，すなわ ちこれを裸眼で行なう場合は，次の 2 つの方法 がある．その一つは輻輳視法で，右眼で左方の 


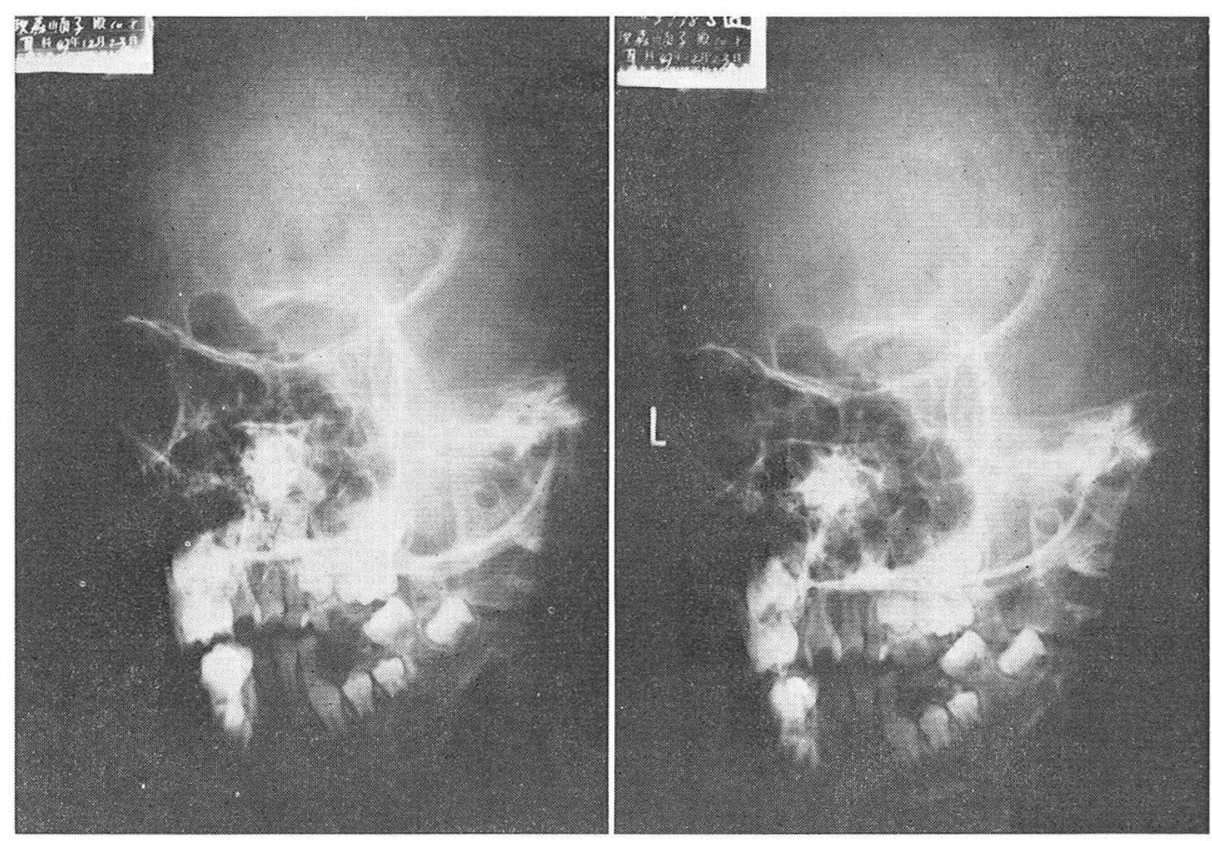

症例 1

視束管骨折

1 枚のフィルムでは明確でない骨折線の方向が立体撮影法では明瞭に判読できる。

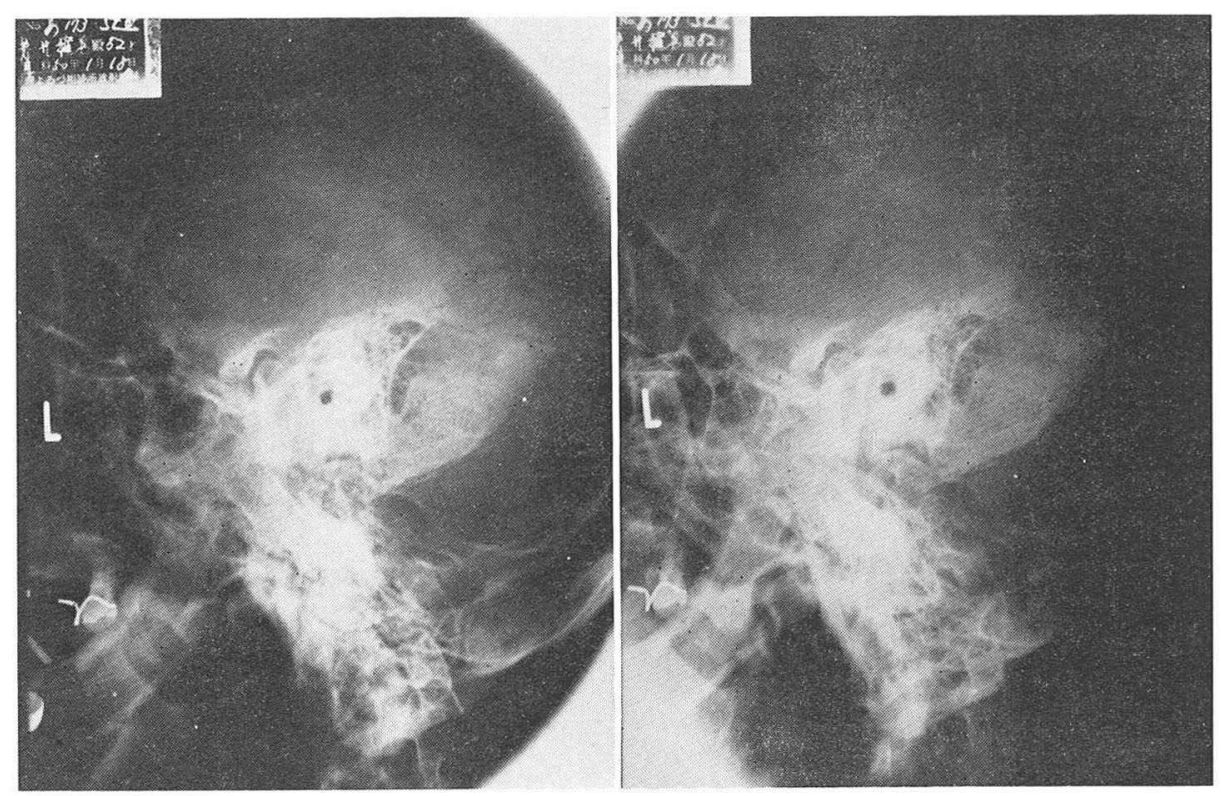

症例 2

迷路周囲炎

めまいを主訴として来院した。立体レ線像より迷路周囲のみ混濁している。手術により迷路周 囲にのみ肉莱炎症を認めた。 
フィルムを, 左眼で右方のフィルムを見る。他 は開散視法で, 右眼で右方のフィルムを, 左眼 で左方のフィルムを見るものである。（佐藤, 吉村, 江藤 ${ }^{4)}$ 図 2 参照)

輻輳視法では 2 枚のフィルムの位置より近く で，且つ両者の中央の点を視つめ，寄り目をし て右眼で左レ線フィルムを, 左眼で右方レ線フ ィルムを視つめる様にする. この際立体像は 2 つのフィルムの中央に浮かんで来るが, 実際の レ線像より縮小された像となる。我々は裸眼輻 輳視法を会得するため, 次の方法を利用してい る. すなわち長さ $20 \sim 30 \mathrm{~cm}$, 幅 $10 \mathrm{~cm}$ 程度のボー ル紙を用意し, その中央部に両眼の間隔に応じ て 2 ケ所咞き穴をあけ，ボール紙の両端を 5 $6 \mathrm{~cm}$ 折り返す.

この様にすると折り返しのため, 右眼では左 側レ線像のみが見え, 左眼では右側レ線像のみ がみえることになる．乙の様にして輻輳視法を 練習した. 一方, 裸眼開散視法の練習は次の様 にして行なった。すなわち無限遠を見るつもり で，眼を開散させ左右の眼でそれぞれ同側のレ 線フィルムを視つめる様にした。との方法を 行なう之, 立体像はフィルム面より後方に, 且 つ実際のレ線像より拡大された像として得られ る. (図 2 参照) 但しての方法は輻輳視法を会 得するより時間を要する. これらの裸眼立体 視法は特別な器具を要しない利点がある.しか し，その欠点は会得に時間が必要であり，また 長時間詳細にレ線像を観察する場合には，眼に 疲労現象があらわれることであろう. 以上の問 題を解決するため, 一般には立体鏡が使われて

考

人体は立体構成をしているにも拘らず，レ線 像では平面として投影される. 従って, 単純レ 線撮影では, 立体感が出ない・重複して投影さ れた病巣像の見誤りが扢てる・病巣の立体的な 拡がりが判別出来ないなどの欠点を有してい る. そてで前後, 側面の 2 方向撮影や, 断層撮 影を行い, その成績を解剖学的知識を駆使して
いる，立体鏡には，(1)反射立体鏡，(2)プリズム 立体鏡，(3)レンズ立体鏡がある。我々はハン ディータイプのプリズム式立体鏡を使用してい る. この場合 2 枚のレ線フィルムの配列を変え ると, 前面加見た立体像, 後面加ら見た立体 像, 左右の逆転した立体像, 以上 4 種の立体像 が得られるととになり, 解剖教育用としても利 用価值がある．またステレオ用に撮られた 2 枚 のレ線フィルムでなくても, 数日間隔で撮られ た単純レ線を 2 枚用いてもその用を足せる. と 云うのは，撮影角度のわずかの違いで立体像が 得られるととが多いからである. この様にして 映し出された立体像では，2枚の写真が互に補 い合うので，1枚のレ線像を別々に観察する場 合に比して, より鮮明な像が得られ, 微細な病 変の観察に適している. また単純レ線像では重 なり合い不明瞭となる構造物む, 立体レ線像で は明瞭に観察出来るととになる。

さて立体的に撮影されたレ線像より, 病巣の 位置を正確に測定する為に色々な測定法が考案 されて来ている.しかし，そのいずれす煩雑で 臨床的には応用し難い. わずかに岡田 ${ }^{5)}$ が提唱 している視差計算を利用した方法が実用性を残 していると思われる。耳鼻科領域では頭蓋とい う骨組織に包含された器官を扱うことが多く, この場合病巣を位置づける周困の骨標識が豊富 であるので，特殊な測定法を駆使する必要はな い.とのととを併せ考えると，耳鼻科領域での 立体レ線撮影法の採用は極めて有用性が高いと 云えよう。

\section{按}

頭の中で立体像に組み立てる方法が一般的に行 われている. 2 方向撮影では, 両者の像は互い に直角をなすので，その立体像をかなり正確に 想像出来るが，人体内での真の立体的構成はあ くまでも推測に止まる. 断層撮影は近年めざま しい改良がなされて来たが, その鮮明度は単純 レ線のそれに比して，はるか隹劣り，またその 
価も高価である。そして単純レ線撮影に比し， 被爆線量が大きいので，その適応は限定され る. 立体撮影法はレ線発見以来特殊検査法とし て取り入れられ，前世紀に既にその方法が確立 されている.しかし現在のとてろ，ての方法は 断層撮影の陰に隠れて忘れ去られた感がある. 我々はこの立体撮影を耳鼻咽喉科領域のレ線揨 断に応用し，その有用性を再認識するてとが出 来た. 特に微細な骨折線の判定や, 腫煌の骨部
浸潤の立体的把握にこの方法は有用性を発揮す るととを知ったままたジィアログラフィーに応 用し診断の的中率を高めえた。乙の撮影法はレ 線撮影装置さえあれば，どてであ撮影出来ると いう簡便さを有しているので，実地瀶床には広 く応用されてよい特徵を有している。またての 方法は耳鼻科領域のレ線読影の教育にも効果的 であると考えている.

\section{む す び}

立体レ線撮影法を耳鼻科領域のレ線診断に用い, 単純撮影や, 断層撮影にない長所をむつととを再 認識した。耳鼻科領域では骨組織に囲まれ，動きがない部位を撮るので，特別な装置を必要としな い. 又描出される骨組織で解剖学的構造が立体化されるので, 病宩の明瞭な位置づけが出来る. こ の様な点を併せ考えると，立体レ線撮影は耳鼻科領域でこそ，その真価を発揮するあのと考える.

稿を終るに臨み，ご校閲いただいた桧 学教㥅に深甚の謝意を表します。

\section{参考文 献}

1 ）佐藤敬明：立体撮影による消化器疾患の新しい誩 断方法. 臨放 18:68〜73, 1973.

2) Hoppenstein, R. : Three-dimensional time sequence roentgenography. JAMA 217 : 922 928, 1971 .

3 ) 藤原文夫 : 立体レントゲン写真の研究. 日本整形 外科学会雑誌 $17: 1581 \sim 1642,1943$.

4 ) 江藤秀雄, 吉村克俊, 作藤幸雄 : X線写真の基礎
知識. 克誠堂, 東京, $234 \sim 241,1965$.

5 ）岡田慶夫, 稲葉宜雄, 埜上誠, 浜川純一：胸部レ 線立体撮影法。胸部外科 7 : 519 531，1954.

原稿到着：昭和 52 年 10 月 22 日

別刷請求先: 宮本和雄

函870 大分市高砂町23の 1

大分県立病院耳鼻咽喉科 